\title{
Phytochemical Analysis, Antioxidant Assay and Antimicrobial Activity in Leaf Extracts of Cerbera odollam Gaertn
}

\author{
Abinash Sahoo, Thankamani Marar*
}

\section{Abinash Sahoo, Thankamani Marar*}

School of Biotechnology and Bioinformatics, D.Y.Patil Deemed to be University, Plot no. 50, Sector 15, CBD Belapur, Navi Mumbai, Maharashtra, INDIA.

\section{Correspondence}

\section{Dr. Thankamani Marar}

School of Biotechnology and Bioinformatics, D.Y.Patil Deemed to be University, Plot no. 50, Sector 15, CBD Belapur, Navi Mumbai, Maharashtra, INDIA.

Phone No: +91- 9892455625

E mail Id:dr.marar@yahoo.com

\section{History}

- Submission Date: 03-12-2017;

- Review completed: 19-12-2017;

- Accepted Date: 10-01-2018

\section{DOI : 10.5530/pj.2018.2.50}

Article Available online http://www.phcogj.com/v10/i2

\section{Copyright}

(c) 2018 Phcog.Net. This is an openaccess article distributed under the terms of the Creative Commons Attribution 4.0 International license.

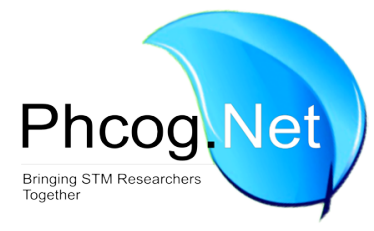

\begin{abstract}
Introduction: In the current study, methanol and aqueous extracts of leaf of Cerbera odollam Gaertn were screened for its antibacterial, antifungal, phytochemicals and antioxidant activities. Phytochemical constituents were investigated both qualitatively and quantitatively. Methods: The leaf extracts of Cerbera odollam Gaertn were prepared by drying and extracted using Soxhlet apparatus into methanol and aqueous media, which were subjected to phytochemical screening. Total phenols, tannins, flavanols, alkaloids and its antioxidant activity were determined using spectroscopic techniques. Antimicrobial activity were determined using well diffusion method. Results: Aqueous extract exhibits higher content of phenols, tannins, flavanols and alkaloids, whereas methanol extract exhibits higher content of anthocyanin and cardiac glycoside respectively. Aqueous extract exhibits higher inhibitory concentration (IC \%) value for DPPH (2, 2-Diphenyl-1-picrylhydrazyl) and $\mathrm{H}_{2} \mathrm{O}_{2}$ radical scavenging assay and reducing power (RP) assay. The methanol extracts exhibited higher inhibitory concentration (IC \%) value in SO and NO radical scavenging assay, exhibiting antioxidant properties in five antioxidant models that were investigated. The methanol extract showed some antibacterial activity against Bacillus subtilis, Staphylococcus aureus, Salmonella typhi and Escherichia coli with inhibitory zone ranging from $2 \mathrm{~mm}$ to $3 \mathrm{~mm}$, whereas the aqueous extract showed no activity. High antifungal activity was found against Saccharomyces cerevisiae and Candida albicans for methanol extract and moderate for aqueous extract with inhibitory zone ranging from $9 \mathrm{~mm}$ to $26 \mathrm{~mm}$. Conclusion: The finding of our study have suggested that the extracts of Cerbera odollam Gaertn, possesses a significant amount of phytochemicals and exhibits antioxidant and antifungal activities.
\end{abstract}

Key words: Cerbera odollam. G, Phytochemicals, Antioxidants, Radical scavenging, Antibacterial, Antifungal.

\section{INTRODUCTION}

Cerbera odollam Gaertn is a tree belonging to the family of Apocynaceae and widely distributed on the coastal area of South East Asia and around the Indian Ocean. The fruits and seeds of C. odollam are highly toxic, containing cardiac glycoside like cerberin, neriifolin, odollin, etc. responsible for $10 \%$ to $50 \%$ of total poisoning cases in the state of Kerala, India. It is used widely for suicide and homicide and hence the name "suicide tree". The tree is also known for various medicinal properties. The latex is known in India for its emetic, purgative and irritant effects. ${ }^{2}$ The oil from the seeds as a cure for, itching or applied to the hair as an insecticide. ${ }^{3}$ The bark and leaf of the plant are traditionally used as emetic and cathartic; kernels are used as an emetic; fruit is used as a cure for hydrophobia. ${ }^{4}$ Its bark and fruits are purgative and used for the treatment of rheumatism. ${ }^{5}$ There are reports of the anti-nociceptive and sedative effects of its barks. ${ }^{6}$ Other research works have reported cytotoxic activity, ${ }^{7}$ its effect on the central nervous system, ${ }^{3}$ purgative and antirheumatic activity, ${ }^{8}$ cardiac stimulant activity, neurological activities, ${ }^{10}$ and cardiotoxic activity. ${ }^{11}$

Medicinal properties of C. odollam are associated with various phytochemicals found in the plant. Different plant species have shown cytotoxic activity against bacteria, fungus, and virus. It also possesses the property to scavenge reactive oxygen species (ROS) which is the major source of primary catalysts that initiate oxidation in vivo and in vitro and create oxidative stress which results in numerous diseases and disorders ${ }^{12,13}$ such as cancer ${ }^{14}$ cardiovascular disease, ${ }^{15}$ neural disorders, ${ }^{16}$ Alzheimer's disease, ${ }^{17}$ mild cognitive impairments, ${ }^{18}$ Parkinson's disease, ${ }^{19}$ ulcerative colitis, ${ }^{20}$ ageing ${ }^{21}$ and atherosclerosis. ${ }^{22}$

Phytochemicals are natural bioactive compounds widely distributed in plants which have been reported to exert multiple biological effects, including antioxidant, free radicals scavenging, anti-inflammatory, anti-cancer, antibacterial, antifungal etc. Therefore, the need arises to evaluate and quantify these phytochemical constituents.

The present study was designed to determine the phytochemical constituents, antioxidant activity, 
antibacterial and antifungal activity in methanol and aqueous extract from the leaves of Cerbera odollam Gaertn through a number of testing methods.

\section{METHODS}

\section{Collection and extraction of plant material.}

Fresh leaf of Cerbera odollam Gaertn collected from Mumbai, Maharashtra, India and authenticated by Blatter herbarium, St Xavier's college, matching with the Blatter herbarium specimen NI 2084 of N.A. Irani. Leaves were cleaned and dried at room temperature for a period of 25 days under shade. Finely ground dried leaf, were weighed and extracted using Soxhlet apparatus by two different solvents methanol and distilled water, $150 \mathrm{ml}$ each for $30 \mathrm{~g}$ of powder. The solution of each extract was then subjected to rotatory evaporator and reduced to $1 / 8^{\text {th }}$ volume. The solution obtained was stored at $4^{\circ} \mathrm{C}$ and appropriately diluted for further studies.

\section{Phytochemical screening (qualitative study)}

\section{Test for Alkaloids - Mayer's Test. ${ }^{23}$}

Few $\mathrm{mg}$ of the residue of each extract was taken separately in $5 \mathrm{ml}$ of $1.5 \% \mathrm{v} / \mathrm{v}$ hydrochloric acid and filtered. These filtrates were treated with Mayer's reagent ( $1.36 \mathrm{~g}$ mercuric chloride and $5 \mathrm{~g}$ of potassium iodide dissolved in $100 \mathrm{ml}$ distilled $\mathrm{H}_{2} \mathrm{O}$ ). The formation of a yellow cream precipitate indicates the presence of alkaloids.

\section{Test for Flavonoids - Alkaline reagent test. ${ }^{24}$}

Two $\mathrm{ml}$ of extracts was treated with few drops of $20 \%$ sodium hydroxide solution. Formation of intense yellow color, which becomes colorless on the addition of dilute hydrochloric acid, indicates the presence of flavonoids.

\section{Test for Saponins - Foam test. ${ }^{25}$}

About $2 \mathrm{ml}$ of distilled water and $1 \mathrm{ml}$ of extract were mixed and shaken vigorously. Formation of a stable persistent froth indicated the presence of saponins.

\section{Test for Tannins - Potassium Dichromate Test. ${ }^{26}$}

The test residue of each extract was taken separately in water, warmed and filtered. If on an addition of a solution of potassium dichromate in test filtrate, dark colour develops, tannins are present.

\section{Test for Carbohydrates - Molisch's test. ${ }^{23}$}

Few drops of Molisch's reagent were added to a $2 \mathrm{ml}$ portion of the extracts. This was followed by addition of $2 \mathrm{ml}$ of conc. $\mathrm{H}_{2} \mathrm{SO}_{4}$ down the side of the test tube. The mixture was then allowed to stand for 2-3 min. Formation of a red or dull violet color at the interphase of the two layers was a positive test for the presence of carbohydrates.

\section{Test for Phenols - Ferric chloride test. ${ }^{27}$}

One $\mathrm{ml}$ of the extracts in $3 \mathrm{ml}$ of distilled water was treated with aqueous $5 \%$ ferric chloride and observed for formation of deep blue or black color indicating presence of phenols.

\section{Test for Cardiac glycosides - Keller Kelliani's test. ${ }^{28}$}

Five $\mathrm{ml}$ of each extract was treated with $2 \mathrm{ml}$ of glacial acetic acid in a test tube and a drop of ferric chloride solution was added to it. This was carefully underlayed with $1 \mathrm{ml}$ concentrated sulphuric acid. A brown ring at the interface indicated the presence of deoxysugar, characteristic of cardenolides. A violet ring may appear below the ring while in the acetic acid layer, a greenish ring may form.

\section{Test for Amino acids -Ninhydrin test ${ }^{29}$}

Two $\mathrm{ml}$ of the filtrate was treated with $2-5$ drops of $1 \%$ ninhydrin solution placed in a boiling water bath for 1-2 min and observed for the formation of purple color.

\section{Test for Sterols - Liebermann-Burchard test ${ }^{28}$}

One ml of the extract was treated with drops of chloroform, acetic anhydride, and conc. $\mathrm{H}_{2} \mathrm{SO}_{4}$ and observed for the formation of dark pink or red color.

\section{Test for Terpenoids - Salkowki's test ${ }^{23}$}

One $\mathrm{ml}$ of chloroform was added to $2 \mathrm{ml}$ of each extract followed by a few drops of concentrated sulphuric acid. A reddish brown precipitate produced immediately indicated the presence of terpenoids.

\section{Test for Quinones ${ }^{30}$}

To $1 \mathrm{ml}$ of extract, $1 \mathrm{ml}$ of conc. $\mathrm{H}_{2} \mathrm{SO}_{4}$ was added. Formation of red color indicated the presence of quinones.

\section{Test for Oxalate 28}

To a $3 \mathrm{ml}$ portion of extracts were added a few drops of ethanoic acid glacial. A greenish black colouration indicates the presence of oxalate.

\section{Test for Proteins. - Biuret Test ${ }^{31}$}

Extracts were treated with $1 \mathrm{ml}$ of $10 \% \mathrm{NaOH}$ solution and heated. To this, a drop of $0.7 \% \mathrm{CuSO}_{4}$ solution was added. Formation of purplish violet color indicates the presence of proteins.

\section{Test for Phlobatannins ${ }^{32}$}

About $2 \mathrm{~g}$ of powdered sample was boiled with $1 \%$ aqueous hydrochloric acid for $5 \mathrm{~min}$. A positive test result was confirmed by deposition of a red precipitate.

\section{Test for Betacyanins ${ }^{32}$}

To $2 \mathrm{ml}$ of plant extract, $1 \mathrm{ml}$ of $2 \mathrm{~N} \mathrm{NaOH}$ was added and heated for $5 \mathrm{~min}$ at $100^{\circ} \mathrm{C}$. Formation of yellow color indicated the presence of betacyanin.

\section{Test for Fatty acids ${ }^{33}$}

Extract $(0.5 \mathrm{ml})$ was mixed with $5 \mathrm{ml}$ of ether and allowed for evaporation, on filter paper and dried. The appearance of transparent spots filter paper indicates the presence of fatty acids.

\section{Estimation of total phenols}

The total phenol content was determined using the Folin-Coicalteu method. ${ }^{34}$ Extract and $0.1 \mathrm{ml}$ of Folin Coicalteu reagent $(0.5 \mathrm{~N})$ were mixed and incubated at room temperature for $15 \mathrm{~min} .2 .5 \mathrm{ml}$ saturated sodium carbonate (20\%) was added and after $30 \mathrm{~min}$ absorbance measured at $760 \mathrm{~nm}$. The total phenol content was expressed in terms of gallic acid equivalent $(\mathrm{mg} / \mathrm{g}){ }^{35}$

\section{Estimation of total tannins}

The total tannins content was determined using Broadhurst and Jones (1978) method. $\mathrm{HCl}(8 \%)$ in methanol and $4 \%$ vanillin in methanol were added to the extracts and absorbance was measured at $500 \mathrm{~nm}$ against blank after 20 mins of incubation at room temperature. The total tannins content was expressed in terms of tannic acid equivalent $(\mathrm{mg} / \mathrm{g}) .^{36}$ 


\section{Estimation of total flavonoids}

The total flavonoids content was determined using aluminium chloride method. ${ }^{37}$ The reaction mixture comprising of extract, aluminium chloride and potassium acetate $(120 \mathrm{mM})$ was incubated at room temperature for $30 \mathrm{~min}$ and absorbance was measured at $415 \mathrm{~nm}$. The total flavonoid content was expressed in terms of quercetin equivalent $(\mathrm{mg} / \mathrm{g}) .^{38}$

\section{Estimation of total alkaloid}

The total alkaloid content was determined using Dragendroff's sodium sulfide method. Mixture containing extract, Dragendroff's reagent and $1 \%$ sodium sulfide was centrifuged to collect the precipitates. It was dissolved in conc. nitric acid and 3\% thiourea was added. The coloured solution was checked for the absorbance at $435 \mathrm{~nm}$. The total alkaloid content was expressed in terms of boldine equivalent $(\mathrm{mg} / \mathrm{g}){ }^{39}$

\section{Estimation of total anthocyanin}

The total anthocyanin content was determined using two buffer systems - potassium chloride buffer, $\mathrm{pH}-1.0(0.025 \mathrm{M})$ and sodium acetate buffer, $\mathrm{pH} 4.5(0.4 \mathrm{M})$. Extract $(0.4 \mathrm{ml})$ was mixed with $3.6 \mathrm{ml}$ of the corresponding buffer and the absorbance was measured against the blank at $510 \mathrm{~nm}$ and $700 \mathrm{~nm}$ respectively in UV spectrophotometer for each extract, the difference between $\mathrm{A}_{510}$ and $\mathrm{A}_{700}$ for $\mathrm{pH}-1$ and $\mathrm{pH}-4.5$ individually was taken. Absorbance was calculated as: $\mathrm{A}=\left(\mathrm{A}_{510}-\mathrm{A}_{700}\right)_{\mathrm{pH} 1.0}-\left(\mathrm{A}_{510}-\mathrm{A}_{700}\right)_{\mathrm{pH} 4.5}$. Monoamine anthocyanin pigment concentration in the extract was calculated as cyanidin-3-glycoside $(\mathrm{mg} / \mathrm{l})=\mathrm{A} \times \mathrm{MW} \times \mathrm{DF} \times 1000 / \mathrm{MA}$. Where A: absorbance; MW: molecular weight (449.2); DF: dilution factor; MA: molar absorptivity $(26,900)$. The total anthocyanin content was expressed in terms of cyaniding-3-glycoside equivalent $(\mathrm{mg} / \mathrm{g}) .^{40}$

\section{Estimation of cardiac glycosides}

The total cardiac glycosides content was estimated according to Solich et al, by some modification. The extracts were filtered using Whatman paper no. 1. To each of the standard and extract solution, $1 \mathrm{ml}$ of Baljet's reagent ( $95 \mathrm{ml}$ of $1 \%$ picric acid $+5 \mathrm{ml}$ of $10 \% \mathrm{NaOH}$ ) was added. After $1 \mathrm{~h}$ of incubation, the mixture was diluted with $20 \mathrm{ml}$ distilled water and absorbance was measured at $495 \mathrm{~nm}$ against a blank containing $\mathrm{D} / \mathrm{W}$. The total cardiac glycoside was expressed in terms of digoxin equivalent $(\mathrm{mg} / \mathrm{g}){ }^{41}$

\section{Evaluation of antioxidant activity DPPH radical scavenging assay}

The free radical scavenging activity was measured by using 2, 2-diphenyl1-picryl-hydrazyl or 1, 1- diphenyl-1-picryl-hydrazyl by the method of McCune and Johns. ${ }^{42}$ The reaction mixture consisted of DPPH in methanol $(0.3 \mathrm{mM})$ and $1 \mathrm{ml}$ of extract. After incubation for $10 \mathrm{~min}$ in dark, the absorbance was measured at $517 \mathrm{~nm}$ against methanol as blank. DPPH scavenging activity was expressed in terms of ascorbic acid equivalent, ${ }^{35}$ as percentage inhibition calculated by the formula:

$$
\% \text { inhibition of DPPH }=\frac{\text { Abs of control }- \text { Abs of sample }}{\text { Abs of control }} \times 100
$$

\section{$\mathrm{H}_{2} \mathrm{O}_{2}$ radical scavenging assay}

The ability of plant extracts to scavenge hydrogen peroxide is assessed according to the method of Ruch. ${ }^{43}$ A solution of hydrogen peroxide (40 mM) was prepared in phosphate buffer $(50 \mathrm{mM}, \mathrm{pH} 7.4)$ and $2 \mathrm{ml}$ of the solution was added to $1 \mathrm{ml}$ extract (1:20 dilutions). The absorbance at $230 \mathrm{~nm}$ was determined after 10 mins in dark, against phosphate buffer as blank. $\mathrm{H}_{2} \mathrm{O}_{2}$ radical scavenging activity was expressed in terms of ascorbic acid equivalent, as percentage inhibition calculated by the formula:

$$
\% \text { inhibition of } \mathrm{H}_{2} \mathrm{O}_{2}=\frac{\text { Abs of control }- \text { Abs of sample }}{\text { Abs of control }} \times 100
$$

\section{Super oxide radical scavenging assay}

The superoxide radical scavenging activity was measured as described by Robak and Gryglewski. ${ }^{44}$ The superoxide anion radicals are generated in $3.0 \mathrm{ml}$ of Tris- $\mathrm{HCl}$ buffer $(16 \mathrm{mM}, \mathrm{pH} 8)$, containing $0.5 \mathrm{ml}$ of NBT ( 0.3 $\mathrm{mM}), 0.5 \mathrm{ml}$ NADH solution $(0.936 \mathrm{mM})$ and $1.0 \mathrm{ml}$ extract ( $1: 100$ dilution). The reaction was started by adding $0.5 \mathrm{ml}$ PMS $(0.12 \mathrm{mM})$ solution to the mixture, incubated at $25^{\circ} \mathrm{C}$ for $5 \mathrm{~min}$ and then the absorbance was measured at $560 \mathrm{~nm}$ against Tris- $\mathrm{HCl}$ buffer as blank. SO anion scavenging activity was expressed in terms of ascorbic acid equivalent, ${ }^{35}$ as percentage of inhibition was calculated by the formula:

$$
\% \text { inhibition of } \mathrm{SO}=\frac{\text { Abs of control }- \text { Abs of sample }}{\text { Abs of control }} \times 100
$$

\section{Nitric oxide radical scavenging assay}

The nitric oxide radical scavenging activity was estimated using Griess's reaction as described by Chanda and Dave. ${ }^{35} 3 \mathrm{ml}$ of sodium nitroprusside in phosphate buffer (10 mM) was added to $2 \mathrm{ml}$ of extract (1:200 dilution). The resulting solution was then incubated at $25^{\circ} \mathrm{C}$ for $60 \mathrm{~min}$. To $5 \mathrm{ml}$ of the incubated sample, $5 \mathrm{ml}$ of Griess reagent (1\% sulphanilamide, $0.1 \%$ naphthyethylene diamine dihydrochloride in $2 \% \mathrm{H}_{3} \mathrm{PO}_{3}$ ) was added and the absorbance of the chromophore formed was measured at $540 \mathrm{~nm}$ against phosphate buffer as blank. NO radical scavenging activity was expressed in terms of ascorbic acid equivalent, as percentage of inhibition was calculated from given formula:

$$
\% \text { inhibition of } \mathrm{NO}=\frac{\text { Abs of control }- \text { Abs of sample }}{\text { Abs of control }} \times 100
$$

\section{Reducing power assay}

Reducing power assay was determined according to the method of Oyaizu. ${ }^{45}$ To the extract, $2.5 \mathrm{ml}$ of phosphate buffer was added. Then 2.5 $\mathrm{ml}$ of potassium ferricyanide was added and the tubes were incubated at $50^{\circ} \mathrm{C}$ for $20 \mathrm{~min}$ (in dark). Then $2.5 \mathrm{ml}$ of TCA was added. The solution obtained was then centrifuged at $3000 \mathrm{rpm}$ for $10 \mathrm{~min}$. Ferric chloride solution $(1 \mathrm{ml})$ was added to the supernatant and the absorbance was read at $700 \mathrm{~nm}$ against phosphate buffer as blank. Reducing power was expressed in terms of ascorbic acid equivalent. ${ }^{46}$

\section{Anti-bacterial assay}

Anti-bacterial assay was determined using agar well diffusion method on nutrient agar plates with wells bored into them. Culture obtained was then spread across the agar and allowed to stand for $10 \mathrm{~min}$, under sterile condition. $100 \mu \mathrm{l}$ of the extract was placed into the well with tetracycline as positive control and sterile distilled water as negative control. After diffusion of the extract, the plates were incubated $37^{\circ} \mathrm{C}$ for $32 \mathrm{hr}$. Zone of inhibition was measured. ${ }^{47}$

Three gram positive organisms and three gram negative organisms namely Corynebacterium diphtheria, Bacillus subtilis, Staphylococcus aureus, Escherichia coli, Salmonella typhi, Klebsiella pneumonia were tested for antibacterial activity against the control tetracycline. 


\section{Anti-fungal assay}

Anti-fungal activity was determined using agar well diffusion method on Sabouraud's agar plates with wells bored into them. Culture obtained was then spread across the agar and allowed to stand for $10 \mathrm{~min}$, under sterile condition. $100 \mu \mathrm{l}$ of the extract was placed into the well with fluconazole as positive control and sterile distilled water as negative control. After diffusion of the extract, the plates were incubated $37^{\circ} \mathrm{C}$ for $32 \mathrm{hr}$. Zone of inhibition was measured. ${ }^{47}$

Two fungal species namely Saccharomyces cerevisiae and Candida albicans were used for studying antifungal activity against the control fluconazole.

\section{RESULTS AND DISCUSSION}

\section{Qualitative screening of C. odollam $G$.}

Results obtained from qualitative screening from leaf extracts of C. odollam. $G$ is presented in Table 1. A total of 16 tests were carried out for detection of different phytochemicals. Of which 13 of them were present in both the extracts. These were alkaloids, flavonoids, tannins, carbohydrates, phenols, cardiac glycosides, amino acids, terpenoids, quinones, oxalates, proteins, fatty acids, and betacyanins.

The results indicate that Cerbera odollam Gaertn holds promise as a source of pharmaceutically important phytochemicals. Hence quantitative determination of these phytochemicals becomes crucial.

Total phenolic, tannin, flavonoid, alkaloid, anthocyanin, cardiac glycoside, chlorophyll contents and antioxidant activities of Cerbera odollam G.

The total phenolic content for dry weight of Cerbera odollam $G$ was estimated to be $72.17 \mathrm{mg} / \mathrm{g}$ for methanolic extracts and $78.46 \mathrm{mg} / \mathrm{g}$ for aqueous extracts (Table 2). Phenols are reactive species towards oxidation and pose biological activity. The process of oxidation and free radicals generation leads to cancer and other diseases. The activity of phenols against this cancer causing process can have therapeutic application in anticancer therapies. Plants having more phenol content show good antioxidant activity indicating a direct correlation between TPC and antioxidant. ${ }^{35}$

The total tannins content of leaf extracts of Cerbera odollam $G$ was estimated to be $44.69 \mathrm{mg} / \mathrm{g}$ dry weight for methanolic extracts and 90.99 $\mathrm{mg} / \mathrm{g}$ dry weight for aqueous extracts (Table 2). Tannins are mostly found in stem and barks of many plants. High concentration of tannins in aqueous leaf extracts shows the presence of the potent antioxidant property. Most of the tannins have antibacterial, antifungal and anticancer properties. Tannin is an astringent, bitter plant polyphenolic compound that binds to and precipitates proteins and various other organic compounds including amino acids and alkaloids. This tannin-protein complex can provide persistent antioxidant activity. ${ }^{35}$

The total flavonols content was estimated to be $25.69 \mathrm{mg} / \mathrm{g}$ for methanolic extracts and $27.59 \mathrm{mg} / \mathrm{g}$ for aqueous extracts (Table 2). The antioxidative properties of flavonoids are due to several different mechanisms, such as scavenging of free radicals, chelation of metal ions, such as iron and copper, and inhibition of enzymes responsible for a free-radical generation. Depending on their structure, flavonoids are able to scavenge practically all known ROS. ${ }^{35}$

The total alkaloid of Cerbera odollam $G$ leaf extract was estimated to be $5.21 \mathrm{mg} / \mathrm{g}$ for methanolic extracts and $13.51 \mathrm{mg} / \mathrm{g}$ for aqueous extracts (Table 2). Most of the alkaloids have local anesthetics and stimulant properties. The alkaloids show cytotoxic activity even in low concentration and other biological activity, showing a wide use in the medical application. Most of the alkaloids are toxic to the human and other organism so it is widely used in medical applications. Alkaloids also show antioxidant properties and anticancer properties like boldine. ${ }^{48}$

The total anthocyanin content of leaf extracts of Cerbera odollam $G$ was estimated to be $0.301 \mathrm{mg} / \mathrm{g}$ dry weight for methanolic extracts and $0.286 \mathrm{mg} / \mathrm{g}$ for aqueous extracts (Table 2). As most of the anthocyanin are coloured pigments found in flower and fruits, the content of anthocyanin was found to be very low in our extracts. Anthocyanin studies have shown monoamine oxidase inhibitor activity connected to the functions in neurogenerative diseases, depression, and anxiety along with neuroprotective and anti-inflammatory activities. It has also been suggested that they show radical scavenging properties and anticancer properties. ${ }^{49,50}$

The total cardiac glycoside content for dry weight of leaf extracts of Cerbera odollam $G$ was estimated to be $0.162 \mathrm{mg} / \mathrm{g}$ for methanolic extracts and $0.137 \mathrm{mg} / \mathrm{g}$ for aqueous extracts. (Table 2). The amount of cardiac glycosides detected in leaf extracts is minor as against larger quantities that have been reported in the fruits of Cerbera odollam. ${ }^{1}$ This makes the fruits considerably toxic since glycosides act as sodium potassium ATPase inhibitor leading to cell death. Cardiac glycosides are used for the treatment of congestive heart failure and cardiac arrhythmia. They also have anticancer properties. ${ }^{51}$

Inhibition concentration is the amount of free radicals scavenged in the determination of antioxidant activity. Phytochemicals act as antioxidants by scavenging the free radicals.

$\mathrm{DPPH}$ is a stable free radical and is widely used to assess the radical scavenging activity of antioxidant compounds. This method is based on the reduction of DPPH in methanol solution in the presence of a hydrogen-donating antioxidant due to the formation of the non-radical form DPPH-H. ${ }^{35}$ The inhibition concentration of DPPH radical scavenging assay for $5 \mu \mathrm{g}$ of leaf extract of Cerbera odollam $G$ was found to be $80.03 \%$ for methanolic extracts and $88.38 \%$ for aqueous extract. (Table 3), as compared to inhibition concentration for $5 \mu \mathrm{g}$ of ascorbic acid that was found to be $88.89 \%$. Aqueous extract shows higher inhibition concentration and scavenged maximum amount of radicals as compared to methanolic leaf extract. The DPPH scavenging activity can be correlated to the presence of flavonoids, showing higher radical scavenging by aqueous extracts. ${ }^{52,53,54}$

$\mathrm{H}_{2} \mathrm{O}_{2}$ is rapidly decomposed into oxygen and water and this may produce hydroxyl radicals $(\mathrm{OH})$ that can initiate lipid peroxidation and cause DNA damage. Antioxidants scavenge hydroxyl radicals. ${ }^{30}$ The inhibition concentration of $\mathrm{H}_{2} \mathrm{O}_{2}$ radical scavenging assay for $20 \mu \mathrm{g}$ of leaf extract of Cerbera odollam $G$ (Table 3) was found to be $49.78 \%$ for methanolic extracts and $70.82 \%$ for aqueous extract. As compared to inhibition concentration for $20 \mu \mathrm{g}$ of ascorbic acid that was found to be $86.47 \%$. Aqueous extract shows higher inhibition concentration and scavenged maximum amount of radicals as compared to methanolic extract. Hydrogen peroxide radical scavenging activity is correlated to the presence of total phenol content. Hence the radical scavenging activity is higher in aqueous leaf extracts. ${ }^{52,53,54}$

Although superoxide anion is a weak oxidant, it gives rise to a generation of powerful and dangerous hydroxyl radicals as well as singlet oxygen, both of which contribute to oxidative stress. The SO radical scavenging activity in $20 \mu \mathrm{g}$ of leaf extracts of Cerbera odollam $G$ was estimated to be $94.57 \%$ in methanolic extract and $91.37 \%$ in aqueous extract indicating a slight difference between the two extracts (Table 3 ), as compared to $20 \mu \mathrm{g}$ ascorbic acid which was found to be $51.61 \%$. SO scavenging activity is correlated to total flavonoids which are greater in aqueous extract but the radical scavenging activity is greater in methanol extract with slight differences in the percentage of inhibition concentration as compared to aqueous extracts. This indicates the presence of some other compound leading to higher radical scavenging activity in methanol extracts as 
Sahoo and Marar.: Phytochemical analysis, antioxidant assay and antimicrobial activity in leaf extracts of Cerbera odollam G.

Table 1: Result of phytochemical screening of leaf extract of Cerbera odollam Gaertn.

\begin{tabular}{cccccc}
\hline Phytochemicals test & $\begin{array}{c}\text { Methanol } \\
\text { extract }\end{array}$ & $\begin{array}{c}\text { Aqueous } \\
\text { extract }\end{array}$ & Phytochemicals test & $\begin{array}{c}\text { Methanol } \\
\text { extract }\end{array}$ & $\begin{array}{c}\text { Aqueous } \\
\text { extract }\end{array}$ \\
\hline Test for alkaloid: & + & + & Test for sterols: & - & - \\
Test for flavonoids : & + & + & Test for terpenoids: & + & + \\
Test for saponins: & - & - & Test for quinones: & + & + \\
Test for tannins: & + & + & Test for oxalate: & + & + \\
Test for carbohydrates: & + & + & Test for proteins: & + & + \\
Test for phenols: & + & + & Test for phlobatannins: & - & - \\
Test for cardiac glycosides: & + & + & Test for betacyanins: & + & + \\
Test for amino acid: & + & + & Test for fatty acids: & + & + \\
\hline
\end{tabular}

Where, "+" is present and “-” is absent.

Table 2: Phytochemical constituents in leaf extract of Cerbera odollam Gaertn.

\begin{tabular}{ccc}
\hline Tests & $\begin{array}{c}\text { Standard equivalent in methanolic } \\
\text { extract. }\end{array}$ & $\begin{array}{c}\text { Standard equivalent in aqueous } \\
\text { extract. }\end{array}$ \\
\hline Total phenol content & $72.167 \pm 0.142 \mathrm{mg} / \mathrm{g}$ & $78.463 \pm 0.0149 \mathrm{mg} / \mathrm{g}$ \\
Total tannin content & $44.691 \pm 0.058 \mathrm{mg} / \mathrm{g}$ & $90.987 \pm 0.115 \mathrm{mg} / \mathrm{g}$ \\
Total flavonoid content & $25.698 \pm 0.025 \mathrm{mg} / \mathrm{g}$ & $27.591 \pm 0.033 \mathrm{mg} / \mathrm{g}$ \\
Total alkaloid content & $5.205 \pm 1.39 \mathrm{mg} / \mathrm{g}$ & $13.511 \pm 1.43 \mathrm{mg} / \mathrm{g}$ \\
Total anthocyanin content & $0.3013 \pm 0.017 \mathrm{mg} / \mathrm{g}$ & $0.2861 \pm 0.104 \mathrm{mg} / \mathrm{g}$ \\
Total cardiac glycoside content & $0.1618 \pm 0.0036 \mathrm{mg} / \mathrm{g}$ & $0.1372 \pm 0.0065 \mathrm{mg} / \mathrm{g}$ \\
\hline
\end{tabular}

Table 3: Inhibitory concentration values for different test performed, in leaf extract of Cerbera odallam Gaertn.

\begin{tabular}{cccc}
\hline Radical scavenging assay & Ascorbic acid (IC \%) & $\begin{array}{c}\text { Standard equivalent in } \\
\text { methanolic extract. (IC \%) }\end{array}$ & $\begin{array}{c}\text { Standard equivalent in } \\
\text { aqueous extract. (IC \%) }\end{array}$ \\
\hline DPPH & $88.849 \%$ at $5 \mu \mathrm{g} / \mathrm{ml}$ & $80.029 \%$ at $5 \mu \mathrm{g} / \mathrm{ml}$ & $88.381 \%$ at $5 \mu \mathrm{g} / \mathrm{ml}$ \\
$\mathrm{H}_{2} \mathrm{O}_{2}$ & $86.470 \%$ at $20 \mu \mathrm{g} / \mathrm{ml}$ & $49.781 \%$ at $20 \mu \mathrm{g} / \mathrm{ml}$ & $70.818 \%$ at $20 \mu \mathrm{g} / \mathrm{ml}$ \\
Super oxide & $51.610 \%$ at $20 \mu \mathrm{g} / \mathrm{ml}$ & $94.567 \%$ at $20 \mu \mathrm{g} / \mathrm{ml}$ & $91.368 \%$ at $20 \mu \mathrm{g} / \mathrm{ml}$ \\
Nitric oxide & $92.718 \%$ at $20 \mu \mathrm{g} / \mathrm{ml}$ & $95.828 \%$ at $20 \mu \mathrm{g} / \mathrm{ml}$ & $95.448 \%$ at $20 \mu \mathrm{g} / \mathrm{ml}$ \\
Reducing power assay & N.A & $0.0486 \pm 0.00252 \mathrm{mg} / \mathrm{g}$ & $0.049 \pm 0.00153 \mathrm{mg} / \mathrm{g}$ \\
\hline
\end{tabular}

Where, "IC \%" is Inhibition concentration \%

compared to higher total flavonoids content in aqueous extracts of C. odollam. .55,35 $^{5}$

Nitric oxide generated from sodium nitroprusside in aqueous solution at physiological $\mathrm{pH}$ interacts with oxygen to produce nitrite ions. Antioxidants act by scavenging the NO radical. ${ }^{35}$ The NO radical scavenging activity (Table 3 ) in $20 \mu \mathrm{g}$ of leaf extracts of Cerbera odollam $G$ was estimated to be $95.83 \%$ in methanolic extract and $95.45 \%$ in aqueous extract indicating a slight difference between the two extracts, as compared to $20 \mu \mathrm{g}$ ascorbic acid found to be $92.72 \%$. NO radical scavenging activity is correlated to the presence of phenols and flavonoid compounds, which is greater in aqueous extract but the NO radical scavenging activity is greater in methanol extract with slight differences in the percentage of inhibition concentration as compared to aqueous extracts. This indicates the presence of some other compound leading to higher radical scavenging activity in methanol extracts as compared to higher phenols and flavonoids content in aqueous extracts. ${ }^{56}$

Reducing power is associated with antioxidant activity and may serve as a significant reflection of the antioxidant activity. Compounds with reducing power indicate that they are electron donors and can reduce the oxidized intermediates of lipid peroxidation processes so that they can act as primary and secondary antioxidants. ${ }^{35}$ The reducing power in $1 \mathrm{gm}$ of extracts of Cerbera odollam $G$ was estimated to be $0.049 \mathrm{mg} / \mathrm{g}$ for methanolic leaf extracts and $0.049 \mathrm{mg} / \mathrm{g}$ for aqueous leaf extracts, (Table 3) ascorbic acid equivalent. The reducing power is mainly correlated to the presence of reductones $\mathrm{F}$ which are strong reducing agents like ascorbic acid, reductive acid, tartronaldehyde, oxalic acid and formic acid. ${ }^{57}$

\section{Antibacterial and antifungal screening of Cerbera odollam $G$}

Zone of inhibition shown by methanol leaf extract of Cerbera odollam $G$ indicates the presence of low antibacterial activity as compared to aqueous leaf extract, which shows no zone of inhibition. These indicate that plant extracts had no antibacterial property. (Table 4)

Zone of inhibition shown by methanol leaf extract of Cerbera odollam $G$ indicates the presence of good antifungal activity better than standard antifungal drug fluconazole as compared to aqueous leaf extract which shows low to the medium zone of inhibition. These indicate that leaf extracts hold a great potential to use as antifungal agents against the fungus like Saccharomyces cerevisiae and Candida albicans. (Table 5 and Figure 1 and 2). 


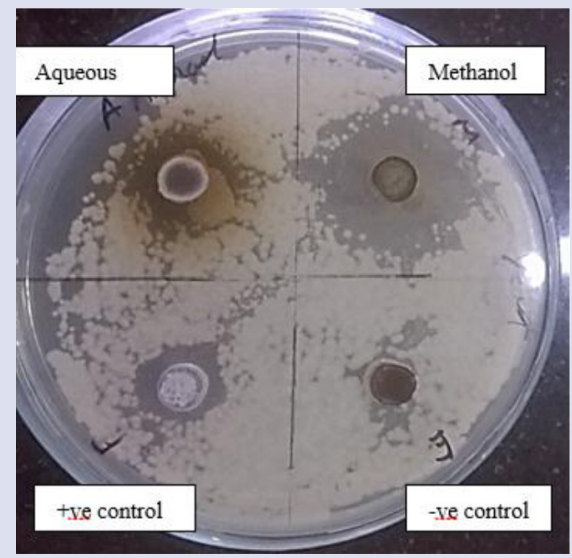

Figure 1: zone of inhibition for the different extracts, against Saccharomyces cerevisiae.

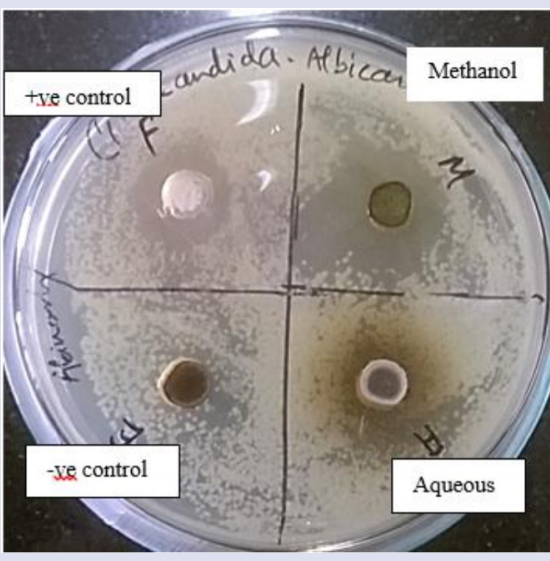

Figure 2: zone of inhibition for the different extracts, against Candida albicans.

Table 4: Results of antibacterial assay by agar well diffusion method of Cerbera odollam G.

\begin{tabular}{cccc}
\hline \multirow{2}{*}{ Organisms } & \multicolumn{3}{c}{ Zone of Inhibition $(\mathrm{mm})$} \\
\cline { 2 - 4 } & $\begin{array}{c}\text { Tetracycline } \\
\text { (positive control) }\end{array}$ & $\begin{array}{c}\text { Leaf Methanol } \\
\text { extract }\end{array}$ & $\begin{array}{c}\text { Leaf Aqueous } \\
\text { extract }\end{array}$ \\
\hline Corynebacterium diphtheria & 30 & Nil & Nil \\
Bacillus subtilis & 22 & 2 & Nil \\
Staphylococcus aureus & 25 & 2 & Nil \\
Salmonella typhi & 27 & 3 & Nil \\
Klebsiella pneumonia & 23 & Nil & Nil \\
Escherichia coli & 25 & 2 & Nil \\
\hline
\end{tabular}

Table 5: Results of antifungal assay by agar well diffusion method for extracts of Cerbera odollam $\mathbf{G}$.

\begin{tabular}{cccc}
\hline \multirow{2}{*}{ Organisms } & \multicolumn{3}{c}{ Zone of Inhibition $(\mathrm{mm})$} \\
\cline { 2 - 4 } & $\begin{array}{c}\text { Fluconazole } \\
\text { (positive control) }\end{array}$ & $\begin{array}{c}\text { Leaf Methanol } \\
\text { extract }\end{array}$ & $\begin{array}{c}\text { Leaf Aqueous } \\
\text { extract }\end{array}$ \\
\hline Saccharomyces cerevisiae & $15 \mathrm{~mm}$ & $26 \mathrm{~mm}$ & $16 \mathrm{~mm}$ \\
Candida albicans & $28 \mathrm{~mm}$ & $25 \mathrm{~mm}$ & $9 \mathrm{~mm}$ \\
\hline
\end{tabular}

\section{CONCLUSION}

In the current investigation, the extracts from Cerbera odollam $G$ were found to be rich in secondary metabolites and possess a significant amount of phytochemicals, antioxidant activity, and antifungal activity. The aqueous extracts showed the higher content of phytochemical constituents like phenols, tannins, flavonols and alkaloids, and higher antioxidant activity for DPPH radical scavenging assay, $\mathrm{H}_{2} \mathrm{O}_{2}$ radical scavenging assay and reducing power assay than methanol leaf extract. The methanol extract showed the higher content of anthocyanin, cardiac glycoside, and higher antioxidant activity for superoxide radical scavenging assay and nitric oxide radical scavenging assay than aqueous leaf extracts. The antioxidant mechanisms of the leaf extracts may be attributed to their free radical-scavenging ability. In addition, phenolic compounds and other phytochemicals appear to be responsible for the antioxidant activity of the extracts. The anti-microbial activity was found to be higher in the methanolic extract as compared to aqueous leaf extract with a low zone of inhibition against bacteria and moderate to the high zone of inhibition against fungus. On the basis of the results obtained, the leaf is rich sources of natural antioxidants and could be developed into drug against diseases such as inflammation, diabetes, cardiac arrest, and hypertension for a variety of beneficial chemo-preventive effects. Isolation and purification of phytochemicals and antifungal constituents of the plant and evaluation of minimum inhibitory concentration (MIC) will provide with an alternate to an existing product and its efficiency.

\section{ACKNOLWEDGEMENT}

We acknowledge School of Biotechnology \& Bioinformatics, D.Y.Patil Deemed To Be University, for all the support to carry out work.

\section{ABBREVIATIONS USED}

v/v: volume by volume; NBT: Nitro Blue Tetrazolium; NADH: Nicotinamide Adenine Dinucleotide; PMS: Phenazine Metho Sulphate; ROS: Reactive Oxygen Species.

\section{CONFLICT OF INTEREST}

The authors have no conflict of interest. 
Sahoo and Marar.: Phytochemical analysis, antioxidant assay and antimicrobial activity in leaf extracts of Cerbera odollam G.

\section{REFERENCE}

1. Gaillard $Y$, Krishnamoorthy A, Bevalot F. Cerbera odollam: a 'suicide tree' and cause of death in the state of Kerala, India. J Ethnopharmacol. 2004;95(2):123-6.

2. Chopra RN, Chopra IC, Handa RL, Kapur DL. Indigenous Drugs of India, Dhur and Sons Private Ltd., Calcutta. $2^{\text {nd }}$ edition. p.316;1958.

3. Hien MT, Navarro DC, Vy T. Toxicity and effects on the central nervous system of a Cerbera odollam leaf extract. J Ethnopharmacology. 1991;34(2-3):201-6.

4. Kirtikar KR, Basu BD. Indian Medicinal Plants, vol. III, 2nd ed., Intl Book Distributors, India.1918;3(2):1552-3.

5. Rollet B. Bibliography on mangroves Res, UNESCO Paris, Information Retrieval Ltd., London. 1600-1975.479;1981.

6. Ahmed F, Hossain MH, Rahman AA, Shahid IZ. Antinociceptive and CNS depressant activity of the bark of Cerbera odollam Gaertn. Orient. Pharm. Exp. Med. 2006:6:344-8

7. Laphookhieo S, Karakai CX, Chantrapromma K. Cytotoxic cardenolide glycoside from the seeds of Cerbera odollam. Phytochemistry J. 2004;65(4):507-10.

8. Yamauchi T, Abe F. Studies on Cerbera IV, polar cardenolide glycoside from the leaves of Cerbera odollam and Cerbera manghas. Chem. Pharm. Bull. 1987;35(7):2744-9

9. Chen JS, Zheng S. Poisonous plants of China, Science press, Beijing. p.75;1987.

10. Iyer GV, Narendranath M. A preliminary report on the neurological manifestation of Cerbera odollam poisoning. Indian J. Med. Res. 1975;63(2):312-4

11. Kini PM, Pai KN. Cardiotoxic effects of Cerbera odollam. Indian Heart J. 1965; 17:263-70.

12. Halliwell $B$, Wiseman $H$. Damage to DNA by reactive oxygen and nitrogen species: role in inflammatory disease and progression to cancer. Biochem $\mathrm{J}$ 1996;313(1):17-29.

13. Rackova L, Oblozinsky M. Free radical scavenging activity and lipoxygenase inhibition of Mahonia aquifolium extract and isoquinoline alkaloids. J Inflammation. 2007;4(1):15.

14. Kinnula V, Crapo J. Superoxide Dismutases in the Lung and Human Lung Diseases. American J of Respiratory and Criti Care Medicine. 2003;167(12): 1600-19.

15. Singh U, Devraj S. Vitamin E, Oxidative Stress, and Inflammation. Annual Review of Nutrition. 2005:25:151-74.

16. Sas K, Toldi J. Mitochondria, metabolic disturbances, oxidative stress and the kynurenine system, with focus on neurodegenerative disorders. J Neurological Sciences. 2007;257(1):221-39.

17. Smith M, Raina A. Oxidative stress in Alzheimer's disease. Biochimica ET Biophysica Acta (BBA) - Molecular Basis of Disease. 2000;1502(1):139-44.

18. Guidi I, Lonati S. Oxidative imbalance in patients with mild cognitive impairment and Alzheimer's disease. Neurobiology of Aging. 2006;27(2):262-9.

19. Bolton J, Trush M. Role of Quinones in Toxicology. Chemical Res in Toxicology. 2000;13(3):135-60.

20. Ramakrishna B, Varghese R. Circulating antioxidants in ulcerative colitis and their relationship to disease severity and activity. J Gastroenterology and Hepatology. 1997;12(7):490-4.

21. Hyun D, Emerson S. Calorie restriction up-regulates the plasma membrane redox system in brain cells and suppresses oxidative stress during aging. PNAS. 2006;103(52):19908-12.

22. Upston J, Stocker R. The role of vitamin E in atherosclerosis. Progress in Lipid Res. 2003;42(5):405-22.

23. Evans WC and Trease GE. Pharmacognosy. 15th ed. London: Saunders Publishers; 42-44. 221-229, 246-249, 226-228;1997.

24. Shalini S, Sampathkumar P. Phytochemical screening and antimicrobial activity of plant extracts for disease management Intl J current science. 2012 209-18

25. Kumar A, llavarasan $R$, Jayachandran T, Decaraman M, Aravindhan P, Padmanaban $\mathrm{N}$, et al. Phytochemical investigation on a tropical plant. Pak J Nutri. 2009;8:83-85

26. Rajalakshmy MR, Sindhu A. "Preliminary phytochemical and antioxidant activity of an ayurvedic formulation: BALARISHTAM". Intl J Res in Ayurveda and pharmacy. 2011;2(6):1645-7.

27. Mace Gorbach SL. Anaerobic bacteriology for clinical laboratories. Pharmacognosy 1963;23:89-91.

28. Ugochukwu SC, Uche A, Ifeanyi O. Preliminary phytochemical screening of different solvent extracts of stem bark and roots of Dennetia tripetala G. Baker Asian J plant science and Res. 2013;3(3):10-13.

29. Yasuma A, Ichikawa T. A new Histochemical staining method for protein. J. Lab.
Clin. Med. Feb. 1953;41(2):296-9.

30. Evans WC, Pharmacognosy. 14th ed. W. B. Saunders Co. Ltd;Singapore. 1996;(9):713-34

31. Brain KR, Turner TD. The practical evaluation of phytopharmaceuticals, 2nd ed Bristol: Wright Science technica. 1975;81- 82.

32. Harborne JB, Phytochemical Methods, Chapman and Hall Ltd., London. 1973;8(9):49-188

33. Ayoola GA, Coker HAB, Adesegun SA, Adepoju-Bello AA, Obaweya K, Ezennia E. Phytochemical screening and antioxidant activities of some selected medicinal plants used for malaria therapy in South Western Nigeria, Trop. J. Pharm. Res 2008;7(3):1019-24.

34. McDonald S, Prenzler P, Robards K. Phenolic content and antioxidant activity of olive extracts. Food Chem. $2001 ; 73(1): 73-84$

35. Chandha S, Dave R. In vitro models for antioxidant activity evaluation and some medicinal plants possessing antioxidant properties: An overview. African $J$ Micro Res. 2009;3(13):981-96

36. Burns RE. Methods of tannin analysis for forage crop evaluation. Georgia Agric Exp. Stn. Tech. Bull. N.S. 1963;32.

37. Chang $\mathrm{C}$, Wen $\mathrm{H}$, Yang M. Estimation of Total Flavonoid Content in Propolis by Two Complementary Colorimetric Methods. J Food Drug Analysis. 2002;10(3):178-82.

38. Mohun AF, Cook IJY. An improved dinitrosalicylic acid method for determining blood and cerebrospinal fluid sugar levels. J Clinical Pathology. 1962;15(2):169-80.

39. Wong SK, Lim XY, Abdullah NP, Nordin FJ. "Antiproliferative and phytochemica analysis of leaf extarcts of ten Apocynaceae sepcies", Pharmacognosy Res. 2011;3(2):100-6

40. Sellappan S, Akoh CC. Flavonoids and antioxidant capacity of Georgia-grown Vidalia onions, J Agri and Food chemistry. 2002;50(19):5338-42.

41. Solich P, Sedliakova V, Karlicek R. Spectrophotometric determination of cardiac glycosides by flow-injection analysis. Anal Chim Acta. 1992;269(2): 199-203.

42. McCune L, Johns T. Antioxidant activity in medicinal plants associated with the symptoms of diabetes mellitus used by the Indigenous Peoples of the North American boreal forest. J Ethno pharmacology. 2002;82(2):197-205.

43. Ruch J, Klaunig J. Prevention of cytotoxicity and inhibition of intercellular communication by antioxidant catechins isolated from Chinese green tea. Carcinogenesis. 1989;10(6):1003-8.

44. Robak J, Gryglewski J. Flavanoids are scavengers of superoxide anions. Biochem. Pharmacol. 1988;37(5):837-41.

45. Oyaizu M. Studies on products of browning reactions: antioxidative activities of products of browning reaction prepared from glucosamine. Japanese J Nutrition. 1986;44(6):307-15.

46. Arulpriya P, Calitha P, Hemalatha S. In vitro antioxidant testing of the extracts of Samanea saman (Jacq.) Merr, J Der chemia sinica. 2010;1(2):73-9.

47. Sen A, Batra A. Evaluation of antimicrobial activity of different solvent extracts of medicinal plant: Melia Azedarach L. Intl J Current Pharmaceutical Res.2002; 4(2):67-73.

48. Zhang Xiao P, Liu Ming S, Zhang Quing J, Kang Li S, Pei Hu Y. Chemicals constituents from leaves of Cerbera manghas.L. J of Asian Natural Product Res. 2009;11(1):75-8

49. Fukumoto L, Mazza G. Assessing antioxidant and prooxidant activity of phenolic compounds. J Agric Food Chem. 2000;48(8):3597-604

50. Giuseppe M. Anthocyanins and heart health, Pacific Agri-Food Res Centre, Agri and Agri Food Canada. 2007:43(4):369-74

51. Sunil Kumar. Cardiac Glycosides as Anticancer Agent. Intl J Res in Pharma and Biomedical Sciences. 2013;4(4):1371-8.

52. PuweiY, Yonghong P. A comparative study on the free radical scavenging activities of some fresh flowers in southern China. LWT-Food Science and Technology. 2008:41(9):1586-91.

53. Thai Pong K, Crosby K. Comparison of ABTS, DPPH, FRAP, and ORAC assays for estimating antioxidant activity from guava fruit extracts. J of Food Composition and Analysis. 2006;19(6):669-75

54. Prakash A, Rigelhof F, Miller E. Antioxidant Activity. (Minneapolis: Medallion Labs). Analytical Progress. Minneapolis Minnesota, USA.2001;19(2):1-6.

55. Chen $\mathrm{H}$, Yen $\mathrm{G}$. Antioxidant activity and free radical-scavenging capacity of extracts from guava (Psidium guajava L.) leaves. J Agri Food Chem. 2007;101 (2):686-94.

56. Sonawane I, Nirmal S. Antioxidant effect of Tephrosia Purpurea L. roots. Intl J Pharma Sciences and Res. 2010;1(5):57-60.

57. Li H, Wang X. Comparative Study of Antioxidant Activity of Grape (Vitis vinifera) Seed Powder Assessed by Different Methods. J Food Drug Analysis. 2008;16(6):1-7. 


\section{SUMMARY}

- Most of the phytochemicals were found to be higher in aqueous extract. Cardiac glycoside were found to be higher in methanol extract.

- Antioxidant assay involving DPPH, $\mathrm{H}_{2} \mathrm{O}_{2}$ \& reducing power, radical scavenging assay where higher for aqueous extract. SO \& NO radical scavenging assay were found to be higher in methanol extract. Exhibiting potent antioxidant properties.

- Anti-microbial assay where found to be higher for methanol extract, exhibiting higher antifungal and lower antibacterial properties.

Cite this article: Sahoo A, MararT. Phytochemical Analysis, Antioxidant Assay and Antimicrobial Activity in Leaves Extracts of Cerbera odollam Gaertn. Pharmacog J. 2018;10(2):285-92. 